\title{
ROLUL ORGANIZAȚIEI NAȚIUNILOR UNITE ÎN APĂRAREA ȘI PROMOVAREA DREPTURILOR FEMEILOR
}

\author{
Simion BELEA*

\begin{abstract}
The Role of United Nations Organization in
\end{abstract} \\ Defending and Promoting Women Rights
}

\begin{abstract}
The Universal Declaration of Human Rights, adopted by the General Assembly of United Nations Organization in 1948, was considered the most important international document for promoting human rights. This process was continued in a very sustained form throughout the Worldwide Conferences of United Nations Organization regarding women rights, events which underline the importance of promoting international cooperation for removing the violence against women in private life and all types of abuse. After analysing the data about this theme, we can say that these actions put a special emphasize on removing the stereotypes and the gender differences, as well as on stopping the violence against women, because of different cultural or religious reasons. The way to progress is very difficult because there are many geographical areas where traditions and religious extremism are very often appealed to in order to justify the use of violence against women.
\end{abstract}

Keywords: United Nations Organization, human rights, women rights, international conferences, religion, private life, gender, abuse.

\section{Introducere}

În anul 1945, luna aprilie, delegații din cincizeci de țări ale lumii s-au întâlnit la San Francisc pentru a pune capăt celui de-al Doilea Război Mondial și pentru a înființa un organism internațional puternic, care să promoveze pacea între popoare și să prevină viitoarele războaie. Acest organism nou creat, cu relevanță internațională, s-a numit Organizația Națiunilor Unite ${ }^{1}$, devenind, după semnarea Cartei Națiunilor Unite ${ }^{2}$ de către membrii săi fondatori, cea mai importantă structură internațională din lume. Idealurile organizației au fost afirmate în preambulul statutului

\footnotetext{
Asistent univ. dr., Universitatea Tehnică din Cluj-Napoca, Centrul Universitar Nord Baia Mare, str. Victoriei,nr. 76, Baia Mare (simionbla@yahoo.com).

${ }^{1}$ Organizaţia Naţiunilor Unite rămâne cea mai importantă organizație internaţională, fiind fondată în anul 1945. A se vedea https://www.un.org/en/.

${ }^{2}$ Carta Națiunilor Unite (în continuare numită Carta) a fost semnată la San Francisco, în data de 26 iunie 1945, odată cu încheierea Conferinței Naţiunilor Unite și a intrat în vigoare la 24 octombrie 1945, fiind constituită dintr-un preambul și o serie de articole grupate în capitole. A se vedea http://legislatie.just.ro/Public/DetaliiDocument/19362.
} 
propus: „Noi, popoarele Naţiunilor Unite, suntem hotărâți să păstrăm generațiile viitoare de flagelul războiului care, de două ori în cursul unei vieți, a provocat omenirii suferințe de nespus", Carta, spre deosebire de Pactul Societății Națiunilor din 1919, angajează organizația să intervină prin propriile sale structuri și institute, special înființate în acest scop, pentru a promova un nivel ridicat de progres social și cultural. Statutul Organizației Națiunilor Unite a intrat în vigoare la 24 octombrie 1945, dată care este celebrată în fiecare an cu sărbătorirea Zilei Națiunilor Unite. ${ }^{3}$

Potrivit acestui document, rolul și misiunea ONU a fost acela de a asigura „pacea mondială”, „respectarea drepturilor omului”, „,cooperarea internațională”, „siguranța persoanei”, „libertate de gandire, religie, cultură și educație” și „respectarea dreptului internațional ${ }^{4,}$, aspecte care, până la acel eveniment măreț, erau considerate doar o utopie. Dacă la început acțiunile Naţiunilor Unite în domeniul politic s-au realizat cu mare dificultate, din cauza contrastului existent între blocurile opuse, în prezent, ONU desfăşoară o vizibilă și apreciată activitate, atât în domeniul economic, cât și în cel social, prin intermediul propriilor organe și institute specializate. Cea mai importantă chestiune dezbătută în cadrul acestei Organizații, în ultimii 70 de ani, a fost și rămâne cea legată de „drepturile omului”, care trebuie aplicate fără nicio distincție de rasă, limbă, culoare și sex ${ }^{5}$. Recunoașterea acestor drepturi face referire și la femei, care au devenit sau au rămas victime ale violenței, în multe state ale lumii drepturile acestora fiind în continuare încălcate, ignorate sau înlocuite cu legi particulare.

\section{Aspecte generale privind rolul Organizației Naţiunilor Unite în apărarea și promovarea drepturilor femeilor}

Dacă analizăm Carta, documentul fondator al Organizației Naţiunilor Unite (ONU), care în momentul înființării sale și-a stabilit atât obiectivele, cât și organismele care să le ducă la îndeplinire (San Francisco, 26 iunie 1945), constatăm că în preambul său, Organizația declară intenția ,de a reafirma credința în drepturile fundamentale ale omului, în demnitatea și valoarea persoanei umane, în egalitatea de drepturi a bărbaților și femeilor”, deși lupta pentru egalitatea de gen era încă în fază incipientă. Conceptul este reafirmat în continuare de articolul 55: „Organizația Națiunilor Unite va promova respectarea universală şi efectivă a drepturilor omului și libertăţilor

\footnotetext{
${ }^{3}$ Ziua de 24 octombrie este sărbătorită de toate statele membre, iar importanța acestui organism mondial este menținerea echilibrului politic, social și cultural în întreaga lume.

4 ,The World Today. The designations employed and the presentation of material on this map do not imply the expression of any opinion whatsoever on the part of the Secretariat of the United Nations concerning the legal status of any country".

${ }^{5}$ Carta Națiunilor Unite. Capitolul I, Scopuri și principi, paragraful 3.
} 
fundamentale pentru toți, fără deosebire de rasă, sex, limbă sau religie. ${ }^{6}$ Promotorii Cartei Națiunilor Unite, făcând referire la „drepturi egale între bărbați și femei”, de fapt puneau accent pe „valoarea persoanei umane”. Niciun document juridic, cu domeniu de aplicare internațional, nu afirma până atunci, cu o asemenea forță, egalitatea tuturor ființelor umane fără nicio deosebire; în același timp, în textul Declarației, identitatea de gen este considerată drept factor de discriminare și, ca atare, inclusă printre prioritățile agendei de lucru. Un pas fundamental pentru drepturile femeii a fost cu siguranță „Declarația Universală a Drepturilor Omului”, din 10 decembrie 1948 (Rezoluția 217A), care conține în preambul o referire explicită la egalitatea drepturilor între bărbați și femei ${ }^{7}$.

În articolele care fac referire la femei, ca subiecți purtători de drepturi, în unele cazuri femeile sunt menționate în mod expres, în altele, referința este cuprinsă în definiția ,fiecare individ”, cum este cazul articolului 2 din declaraţia Drepturilor Omului, potrivit căruia: „Fiecărui individ îi aparţin toate drepturile și libertățile stabilite în prezenta Declaraţie, fără nicio deosebire de rasă, culoare, sex, limbă, religie, ... sau orice altă condiție".

Articolul 16 stabilește că bărbații și femeile au drepturi egale în ceea ce privește căsătoria, pe perioada căsătoriei și în momentul dizolvării acesteia; articolul 23 consacră dreptul egal la muncă și o remunerație egală pentru o muncă de valoare egală; articolul 25 protejează maternitatea; articolul 26 garantează dreptul egal la educație ${ }^{8}$. Convenţia din 2 decembrie 1949, privind abolirea traficului de persoane și exploatarea prostituției, intrată în vigoare la 25 iulie 1951 a avut in rol primordial în promovarea drepturilor femeii ${ }^{9}$. Convenția stabilește pedepsirea celor care favorizează prostituția altor persoane din motive economice, chiar dacă există consimțământul acestora. De asemenea, la 20 decembrie 1952, Adunarea Generală a adoptat Convenția privind drepturile politice ale femeilor, care a

\footnotetext{
${ }^{6}$ Articol reafirmat în Curtea europeană a Drepturilor Omului, Council of Europe F-67075 Strasbourg cedex, în www.echr.coe, data accesării 20.10.2019.

${ }^{7}$ United Nations. Human Rights. Office of the High Commissioner, Universal Declaration of Human Rights, in https://www.ohchr.org/en/udhr/pages/Language.aspx?LangID=itn, data accessării 19.10.2019.

${ }^{8}$ Declaraţia Universală a Drepturilor Omului, adoptată de Adunarea Generală a Organizației Națiunilor Unite la 10 de septembrie 1948. Dreptul la educaţie este menţionat în numeroase documente ale Naţiunilor Unite şi în documente privind drepturile omului, inclusiv în Pactul internaţional cu privire la drepturile economice, sociale şi culturale (Articolul 14) şi Convenţia cu privire la drepturile copilului (Articolele 28 şi 29).

9 Aprobată de Adunarea generală a Naţiunilor Unite prin Rezoluţia 317 (IV), din 2 decembrie 1949 şi intrată în vigoare la 25 iulie 1951, conform dispoziţiilor art. 24. România a aderat la Convenţie la 10 decembrie 1954, prin Decretul nr. 482, publicat în „Buletinul Oficial al României“, Partea I, nr. 46 din 10 decembrie 1954.
} 
stabilit pentru femei dreptul de a vota, de a alege și de a putea exercita funcții publice, Convenție care a intrat în vigoare în 31 martie $1953 .{ }^{10}$

În ceea ce privește problemele legate de muncă, există diferite convenții ale OIM (Organizația Internaţională a Muncii): Convenția nr. 89 privind munca de noapte pentru femeile angajate în industrie ( 9 iulie $1948^{11}$ ): Convenția nr.100 privind remunerația echitabilă (29 iunie 1951) prin care statele semnatare se angajează să intervină în legislaţia naţională pentru a elimina orice formă de discriminare în ceea ce privește remunerarea bărbaților și femeilor pentru muncă de valoare egală; Convenția nr. 103 privind protecția maternității pentru femeile angajate (28 iunie 1952); Convenţia nr. 111 împotriva discriminării la locul muncă (25 iunie 1958), care prevede că fiecare stat trebuie să promoveze egalitatea de șanse și de tratament pentru a pune capăt tuturor formelor de discriminare la locul de muncă $^{12}$, fiind interzisă orice discriminare bazată pe rasă, culoare de sex, religie, naționalitate, opinii politice sau origini sociale.

În 1960, Organizația Naţiunilor Unite pentru Educație, Știință și Cultură - UNESCO a adoptat Convenția împotriva discriminării în educație pentru a elimina orice discriminare bazată pe sex în mediul educaţional și pentru a adopta unele măsuri menite să promoveze egalitatea de șanse și de tratament. $^{13}$

Aparţin aceleiaşi perioade multe rezoluții adoptate de ONU, care conțin norme și dispoziții referitoare la femei, deși nu se referă la situația specifică a acestora. Respectivele documente se referă la două situații în care drepturile femeii suferă încălcări grave sau sunt complet negate: în situații de război și de sclavie. $\mathrm{Cu}$ privire la această ultimă situaţie, Conferința Plenipotențiarilor ONU, din data de 7 septembrie 1956, a adoptat Convenția suplimentară privind abolirea sclaviei, comerțul cu sclavi și orice altă practică similară, intrată în vigoare la $30.04 .1957^{14}$. Trebuie amintit

10 România a ratificat Convenţia prin Decretul nr. 222 din 2 iunie 1954, publicat în „Buletinul Oficial al României”, partea I, nr. 28 din 10 iunie 1954.

${ }_{11}$ Textul a intrat în vigoare la 18 ianuarie 1958 și a fost publicat în Monitorul Oficial al României, http://www.expert-monitor.ro/expert-monitor/Demo/index.jsp, data accesării: 12.06.2019.

${ }^{12}$ România a ratificat Convenţia prin Decretul nr. 284, publicat în „Buletinul Oficial al României“, partea I, nr. 81, din 6 iunie 1973.

13 Organizația pentru Educație, Știință și Cultură (UNESCO), cu sediul la Paris, funcționează sub auspiciile Consiliului Economic și Social al Naţiunilor Unite. Această organizație a luat în considerare condiția femeilor, atât în ceea ce privește posibilitatea reală de acces la educație pentru femei (încă foarte limitată în multe țări), cât și în ceea ce privește discriminarea culturală împotriva femeilor, cum ar fi de exemplu discriminare în accesul la învățământ sau stereotipurile sexuale întâlnite în manuale.

${ }^{14}$ Semnată la Geneva, la 25 septembrie 1926, și intrată în vigoare la 9 martie1927, conform dispoziţiilor art. 12, Convenţia a fost amendată prin Protocolul elaborat la sediul Naţiunilor Unite, New York, la 7 decembrie 1953; Convenţia amendată a intrat în vigoare la 7 iulie 1955, dată la care amendamentele expuse în anexa Protocolului din 7 decembrie 1953 au 
faptul că interzicerea sclaviei a fost deja reiterată de către articolul 4 din Declarația Universală a Drepturilor Omului din1948 ${ }^{15}$.

În ceea ce privește situațiile de conflict armat, caz în care femeile suportă consecințele directe și indirecte ca victime ale distrugerii materiale, ale violenţei morale și fizice, sărăcirea, pierderea afecțiunilor și orice altă pierdere, care revine populației civile, cele patru convenții de la Geneva, semnate la 12 august 1949 de către Conferinţa diplomatică a plenipotențiarilor ONU și cele două protocoale adiţionale din 8 iunie 1977, reiterează drepturile femeilor în aceste condiții specifice, argument dezbătut în cadrul a 40 de articole din totalul celor 560 care le compun.

\section{Drepturile femeilor prin prisma Conferințelor Mondiale,} organizate de ONU în anii 1975, 1980, 1985, 1995, 2000, 2005

În primele decenii, activitatea ONU în domeniul apărării femeilor s-a axat în principal pe codificarea drepturilor civile ${ }^{16}$ și legale ale femeilor, dar şi pe colectarea de date cu privire la statutul lor în lume, însă devenise din ce în ce mai clar că legile nu erau suficiente pentru a garanta egalitatea drepturilor femeilor ${ }^{17}$.

În data de 11 noiembrie 1972, o rezoluție a Adunării Generale a proclamat anul 1975 ca fiind „Anul Internațional al Femeilor”, al cărui obiectiv era crearea unei societăți în care populația feminină să poată participa activ la viața politică, socială și economică din țara de origine. De asemenea, a fost recunoscut faptul că violența este strâns legată de condiția social-globală în care se găsesc femeile. Astfel, de exemplu, sărăcia economică este un factor care expune unui risc mai mare de abuz de orice fel, chiar și sexual. ${ }^{18}$ Practic, lupta pentru egalitate a intrat în a doua fază, mai precis odată cu convocarea conferințelor mondiale de către ONU, în scopul dezvoltării unei strategii globale pentru garantarea drepturilor femeilor.

intrat în vigoare conform art. III al acestui Protocol. România a ratificat prezenta Convenţie prin Decretul nr. 988, publicat în „Buletinul Oficial al României”, partea I, nr. 76 din 1 aprilie 1931.

15 „Niciun individ nu poate fi ținut într-o stare de sclavie sau de servitute, sclavia și comerțul cu sclavi vor fi interzise sub orice forma”, inclusiv cea sexuală.

${ }^{16}$ Drepturile civile sunt cele care privesc dreptul la viaţă, libertatea şi securitatea persoanei, oferind persoanei protecţie împotriva violenţei fizice, torturii şi tratamentelor inumane, arestării arbitrare, detenţiei, exilului, sclaviei şi servituţii, restricţionării libertăţii de mişcare şi libertăţii de gândire, conştiinţă şi religie, interferenţei cu dreptul unei persoane la viaţă privată şi cu dreptul la proprietate.

17 „Le conferenze internazionali sulla donna”, în http://unipd-centrodirittiumani.it/it/schede/ Le-Conferenze-internazionali-sulla-donna/382, data accesării: 12 octombrie 2019.

18 În acest nou context de deschidere către problematica drepturilor femeilor, a avut loc prima conferință mondială, desfăşurată în Mexico City, în anul 1975. 
Conferinţele Mondiale privind femeile, convocate de ONU în ultimele decenii, au rămas în centrul agendei globale referitoare la egalitatea între bărbați și femei, prin identificarea obiectivelor comune și adoptarea unui plan de acțiune privind schimbarea modului în care femeile sunt percepute, precum și avansarea condiției feminine.

\subsection{Prima Conferință ONU din Mexico City (1975) privind dialogul global}

Adunarea Generală a Națiunilor Unite, în anul 1972, a primit propunerea din partea Comisiei privind Condiţia Femei $(\mathrm{CSW})^{19}$ de a proclama anul 1975 - „Anul Internațional al Femeii”,20, pentru a reaminti comunității internaţionale că discriminarea faţă de femei continuă să fie o problemă în cea mai mare parte a lumii ${ }^{21}$.

Conferința Mondială de la Mexico City, organizată de ONU, cu privire la statutul și rolul femeilor, a fost convocată pentru a concentra atenția internațională asupra necesității de a dezvolta obiective orientate spre viitor, strategii eficiente și planuri de acțiune privind progresul femeilor. În acest sens, a fost adoptat un plan de acțiune la nivel mondial, care a prezentat liniile directoare pe care guvernele și comunitățile trebuie să le urmeze pentru a atinge obiectivele stabilite de Adunarea Generală $\breve{a}^{22}$.

Printre obiectivele prioritare analizate și dezbătute au fost: egalitatea deplină între sexe şi eliminarea discriminării sexuale; integrarea şi participarea deplină a femeilor la dezvoltare; contribuția femeilor la consolidarea păcii în lume.

Înainte de acest eveniment, femeile erau considerate destinatari pasivi, care au nevoie de sprijin și asistență, odată cu realizarea acestei conferințe, femeile erau considerate parteneri egali și membrii cu drepturi depline, cu aceleași resurse și oportunități. Conferința a invitat guvernele să formuleze noi strategii naționale, să identifice obiective și priorități în încercarea lor de a promova participarea egală a femeilor. Până la sfârșitul termenului stabilit de ONU, cele 127 state membre au răspuns prompt acestei solicitări, prin crearea unor mecanisme naționale și a unor noi instituții pentru promovarea

\footnotetext{
${ }^{19}$ Comisia pentru Condiția Femeilor este principalul organism interguvernamental al Organizației Națiunilor Unite, care promovează egalitatea de gen.

${ }^{20}$ „First World Conference on Women, Mexico 1975. Choike, Third World Institute”, în https://www.unsystem.org/content/first-world-conference-women-1975-0, data accesării: 23.11.2019.

${ }^{21}$ „Le conferenze internazionali sulla donna”, în http://unipdcentrodirittiumani.it/it/schede/Le-Conferenze-internazionali-sulla-donna/382, data accesării: 10 octombrie 2019.

${ }^{22}$ Conny Hermann, Verlag J.H.W. Dietz Nachf, Das Recht auf Weiblichkeit: Hoffnung im Kampf gegen die Genitalverstümmelung, Taschenbuch, 2000.
} 
politicilor, cercetărilor și programelor menite să promoveze progresul și participarea femeilor la dezvoltarea societății.

După un an de la organizarea acestui eveniment, ONU a creat Fondul de Dezvoltare a Naţiunilor Unite pentru Femei (UNIFEM) ${ }^{23}$ și Institutul Internaţional de Cercetare și Formare pentru Promovarea Profesională a Femeilor (INSTRAW), cu scopul de a garanta cadrul instituţional necesar pentru cercetarea, formarea și realizarea activităților operative în favoarea promovării femeilor ${ }^{24}$. Trebuie subliniată, de asemenea, prezența și participarea puternică a femeilor la acest forum internațional şi rolul important pe care această întâlnire 1-a avut, contribuind, prin intermediul schimbului intercultural, la demararea unui proces de unificare a mișcării feministe, care a devenit cu adevărat internațională.

\subsection{Conferința de la Copenhaga, Danemarca (1980), referitoare la procesul de revizuire}

Cea de-a doua Conferință Mondială organizată de ONU, în anul 1980, la un interval de cinci ani de la prima conferință, a fost considerată un început al procesului de revizuire în acest domeniu. Se poate afirma că a existat un consens general datorită faptului că au fost înregistrate unele progrese în momentul în care la Copenhaga s-au întâlnit reprezentanţi din 145 de state membre si aproximativ 8000 de reprezentanţi ale ONG-urilor provenite din 187 de state $^{25}$.

Rolul și obiectivele acestei Conferințe era acela de a revizui și evalua Planul de Acțiune Mondială din 1975. În urma chestiunilor abordate în Mexico Citty, a fost subliniat faptul că recunoașterea de iure a drepturilor femeilor nu implică automat posibilitatea de a beneficia de aceste drepturi, datorită structurilor și obiceiurilor sociale discriminatorii. Din acest motiv, Conferința s-a concentrat pe trei domenii, și anume: educația, sănătatea și munca, în privința cărora s-au dezvoltat o serie de măsuri specifice și acțiuni orientate să aducă schimbări concrete în sectoarele în care femeile se confruntă cu o mai mare discriminare. În cadrul Conferinței ${ }^{26}$ a fost prezentată, de asemenea, „Convenția ONU pentru eliminarea tuturor formelor de discriminare împotriva femeilor" (CEDAW), elaborată de

\footnotetext{
${ }^{23}$ Fondul ONU de Dezvoltare pentru Femei a fost înființat în decembrie 1976, inițial, ca Fondul voluntar pentru desfăşurarea Deceniului Naţiunilor Unite pentru femei în Anul International al Femeii.

24 Începând cu 1979, Institutul Internațional de Cercetare și Formare pentru Promovarea Profesională a Femeilor (The United Nations International Research and Training Institute for the Advancement of Women o UN-INSTRAW) este principalul institut de cercetare al Naţiunilor Unite care contribuie la dezvoltarea capacităţii și competențelor, la gestionarea și formarea cunoștințelor pentru a atinge egalitatea de gen și crșterea gradului de autonomie în rândul femeilor.

${ }^{25}$ Gil Loescher, Refugee and international relations, Oxford, Clarendon Press, 1990.

${ }^{26}$ Conferința de la Copenhaga, organizată de ONU în perioada 14-30 iulie 1980.
} 
Comisia pentru statutul femeilor și aprobată de Adunarea Generală la 19 decembrie 1979. CEDAW a fost primul instrument internaţional obligatoriu din punct de vedere juridic ${ }^{27}$, axat pe conceptul de nediscriminare. Importanța acestui document constă în faptul că a contribuit la depăşirea crizei care a afectat Comisia ONU pentru Statutul Femeii/ Commission on the Status of Women $(\mathrm{CSW})$ în ultimii $\mathrm{ani}^{28}$, a cărei existență fusese chiar pusă la îndoială, atât din cauza inființării altor agenții „,competitive” în domeniul protecției drepturilor omului, cât și în ceea ce privește obiectivele stabilite la începutul mandatului său, rezultatele obținute fiind considerate destul de modeste.

Conținuturile Conferinței și liniile directoare privind punerea lor în aplicare au fost incluse mai târziu în „Programul de acțiune Mondial de la Copenhaga", deși acest lucru nu a fost votat în unanimitate, citând o multitudine de factori responsabili pentru discrepanța dintre drepturile legale $^{29}$ și capacitatea femeilor de a-și exercita respectivele drepturi. În concluzie, în cadrul discuțiilor s-au constatat următoarele: lipsa implicării suficiente a bărbaților în îmbunătățirea rolului femeilor în societate; o voință politică insuficientă; eșecul în a recunoaște valoarea contribuțiilor femeilor în societate; lipsa de atenție, în faza de planificare, la nevoile speciale ale femeilor; lipsa femeilor în funcții înalte, care privesc luarea deciziilor; inadecvarea serviciilor necesare pentru a sprijini rolul femeilor în viața națională, cum ar fi cooperativele, centrele de îngrijire zilnică și facilităţile de creditare; deficitul general al resurselor financiare necesare; lipsa de conștientizare a femeilor cu privire la oportunitățile existente.

\subsection{Conferința din Nairobi, Kenia (1985), referitoare la viitoarele strategii de acțiune}

Cea de-a treia Conferință mondială a ONU privind femeile a fost convocată la Nairobi, Kenia, în perioada 15-26 iulie 1985, cu ocazia „Deceniului Internațional ONU pentru condiția femeii”, și a avut misiunea de a evalua rezultatele deceniului ONU de la primele două Conferinț $^{30}$. Conform statisticilor internaţionale, la eveniment au participat circa 1.900 de delegați din 157 de state, precum şi 14.000 de reprezentanţi ai ONG-urilor din 150

\footnotetext{
${ }^{27}$ Convenția privind eliminarea tuturor formelor de discriminare împotriva femeilor a fost adoptată şi lansată spre semnare de Adunarea Generala a Naţiunilor Unite printr-o rezoluție din data de 18 decembrie 1979. Aceasta a intrat în vigoare la 3 septembrie 1981 în toate statele member ale ONU.

${ }^{28}$ Comisia pentru Condiția Femeilor a fost înființată prin rezoluția Consiliului Economic și

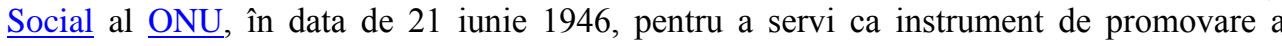
drepturilor femeilor și la documentarea experiențelor acestora din viața de zi cu zi.

${ }^{29}$ Risoluzione dell'Assemblea Generale, N. 3520, 15 Dicembre 1975.

30 https://it.wikipedia.org/wiki/Conferenza_mondiale_sulle_donne, data accesării:
} 10.11.2019. 
de țări, care au desfășurat 1.800 de activități, seminarii și grupuri de lucru, alături de 37 de reprezentanţi ai agențiilor ONU și alte organizații acreditate, precum și 16 delegații ale unor organizații neguvernamentale ${ }^{31}$.

Conferința s-a caracterizat prin depășirea tensiunilor întâlnite în cadrul evenimentelor anterioare de acest fel deoarece dezbaterea internaţională largă, întâlnirile și colaborarea din anii precedenți între actorii implicaţi, au favorizat nașterea unei noi mișcări feministe internaționale, mai puternice și mai coerente. ${ }^{32}$ Acest lucru a fost sprijinit, de asemenea, de munca intensă a agențiilor ONU și a altor organizații în colectarea, compararea și difuzarea datelor și experiențelor privind situația femeilor în lume.

$\mathrm{Cu}$ toate acestea, statisticile au arătat că femeile, care au beneficiat de măsurile dezvoltate și implementate în cadrul „Deceniului Internaţional ONU pentru condiția femeii”, constituiau doar o mică parte din populația feminină mondială, aceasta fiind situată în special în țările occidentale. În mod particular, Conferința a identificat câteva domenii critice, care impun angajamentul imediat din partea comunității internaționale, cum ar fi: sărăcia, conflictele armate, violența în familie și marginalizarea. Prin urmare, acțiunea inițiată în Mexico City nu putea fi considerată încheiată odată cu Conferința de la Nairobi.

Din acest motiv, a fost adoptat un document intitulat „Strategii Viitoare de Acțiune Nairobi-NFLS", în scopul atingerii obiectivelor stabilite la începutul Deceniului Internațional, până în anul 2000. În special, acțiunea NFLS a fost împărțită în trei domenii specifice: dezvoltarea instrumentelor legislative adecvate; egalitate de șanse privind participarea socială; egalitate în procesul politic şi de luare a deciziilor.

Prin urmare, conceptul de egalitate nu a fost înțeles doar ca o lipsă a discriminării, ci într-un sens mai larg, ca posibilitate de a realiza și de a se bucura de propriile drepturi și de a participa din plin, cu propriile abilități și așteptări, la progresul social. În acest sens, egalitatea nu este considerată doar scop, ci și mijloc, pentru a crea o societate mai dreaptă. ${ }^{33}$

\footnotetext{
${ }^{31}$ http://unipd-centrodirittiumani.it/it/schede/Le-Conferenze-internazionali-sulladonna/382, data accesării: 10.11.2019.

${ }^{32}$ La Nairobi, în 1985, au fost elaborate strategiile pe termen lung (până în anul 2000), cu privire la progresul femeilor, care oficializează un angajament mai mare din partea ONU pentru problemele de discriminare legate de gen.

${ }_{33}$ Giuseppe Sperduti, Studi in onore di Giuseppe Sperduti: fonti internazionali e rapporti fra ordinamenti; l'individuo nel diritto internazionale; altri contributi, Milano, Giuffré, 1984. Jost Delbrück and Rüdiger Wolfrum, German year Book of international law, vol. 36, Berlin, Duncker \& Humblot, 1993.
} 
3.4. Conferința de la Beijing, China (1995): un nou angajament al Naţiunilor Unite privind condiția femeii

A patra Conferință mondială a femeilor a avut loc la Beijing, între 4 și 15 septembrie 1995. La această Conferință au participat 5307 delegați din 189 de guverne. În același timp, 31.000 de femei au participat la Forumul ONGurilor de la Huairou, reprezentând mai mult de 2.000 de organizații din circa 194 de țări diferite.

Declarația finală a exprimat angajamentul guvernelor „de a promova obiectivele de egalitare, dezvoltare și pace pentru toate femeile, în orice loc și în interesul întregii omeniri”, ascultând „,vocea femeilor din întreaga lume", în ceea ce privește respectarea diversităților reciproce. De o importanță fundamentală a fost „Platforma de acțiune",34, un document alcătuit din 362 de paragrafe, reunite în șase capitole, în care au fost elaborate doisprezece domenii critice ${ }^{35}$ cu privire la promovarea drepturilor femeilor, urmate de o serie de orientări.

Platforma de acțiune aprobată de Conferința de la Beijing poate fi considerată ,textul politic cel mai relevant și cel mai consultat de către femeile din întreaga lume". De fapt, aceasta reprezintă rezultatul unei lungi dezbateri în care femeile au fost obiectul și subiectul unui efort colectiv de identificare a obstacolelor în calea egalității de gen și de propunere a unor soluții extrase din experiența în domeniu și din schimbul de bune practici între state și organizații ${ }^{36}$.

Plecând de la Beijing, mișcările din întreaga lume și-au exprimat revendicarea de a ,privi lumea cu ochii unei femei” și au afirmat că „drepturile femeilor sunt drepturile omului și că drepturile omului sunt drepturi ale femeilor. În cadrul acestei conferințe au fost elaborate, de asemenea, două concepte care au devenit fundamentale în dezbaterea privind problemele de gen, și anume: empowerment şi gender mainstreaming ${ }^{37}$, adică ,emanciparea” și ,,integrarea dimensiunii de gen”.

\footnotetext{
${ }^{34}$ Această platformă de acțiune face referire la combaterea violenței împotriva femeilor, a discriminării, la promovarea sănătății, dar și la aspecte legate de extirparea conflictelor armate, economie, mass-media, poziții și procese decizionale, mecanisme menite să promoveze egalitatea, educația și formarea.

35 Declarația de la Beijing și programul aferent de acțiune au fost considerate cel mai progresiv proiect de promovare a drepturilor femeilor conceput vreodată. Platforma a identificat 12 sectoare critice, care astăzi constituie liniile directoare pentru monitorizarea situației femeilor în lume. Idealul care a inspirat această iniţiativă a fost crearea unei lumi în care orice femeie și fată să își poată exercita toate drepturile, cum ar fi acela de a trăi liberă, fără violență, dreptul la studiu, la luarea deciziilor etc.

${ }^{36}$ I diritti umani delle donne: dalla Dichiarazione Universale del 1948 alla Conferenza di Pecchino del 1995, in https://www.studiocataldi.it/doc/olivieri/cap2.asp, data accesării: 03.12.2019.

${ }^{37}$ Gender mainstreaming este o strategie internațională privind realizarea egalității de gen. La nivel european, gender mainstreaming este recunoscut ca un drept fundamental și o
} 
În timp ce conceptul de empowerment se referă la eliminarea tuturor obstacolelor și participarea deplină a femeilor la viața socială, culturală, economică și politică a unei țări, conceptul de ,integrare a dimensiunii de gen”, propus în cadrul Conferinței de la Nairobi și elaborat în continuare la Beijing, indică adoptarea unei abordări care ia în considerare diferitele consecințe pe care procesele decizionale le au asupra bărbaților și femeilor $^{38}$. În acest sens, a fost adoptată o declarație politică și un acord privind ulterioarele acțiuni și inițiative pentru a pune în aplicare Declarația de la Beijing și „Platforma de Acțiune”.

\subsection{Adunarea de la New York (2000) cu privire la rolul femeilor în secolul XXI}

În iunie 2000, la 5 ani după Conferința de la Beijing, reprezentanții diferitelor guverne s-au întâlnit într-o sesiune specială a Adunării Generale a ONU pentru a revizui programele cuprinse în „Platforma de acțiune”. Peste o sută de delegații guvernamentale, optzeci de miniștri ai ministerelor pentru egalitatea de șanse nou înființate în mai multe state, precum și reprezentanții unor organizațiilor neguvernamentale au luat parte la conferința cu titlul „Beijing +5 ”. În cadrul acestei sesiuni a fost criticat faptul că nu toate statele au abrogat legile cu un conţinut discriminatoriu, aceasta fiind doar o mică componentă a inegalității sociale care afectează zilnic femeile din întreaga lume.

Cel mai izbitor fapt este că respectivele legi sunt încă în vigoare la 5 ani de la Conferința de la Beijing, la 20 de ani de la adoptarea Convenției pentru eliminarea tuturor formelor de discriminare si la 50 de ani după adoptarea Declarației Universale a Drepturilor Omului ${ }^{39}$, declarație prin care s-a proclamat că toate ființele umane se nasc libere și egale în demnitate și drepturi. Din punct de vedere internațional, acest lucru este inacceptabil și arată lipsa totală de respect din partea respectivelor state pentru conceptul de egalitate și nediscriminare.

Scopul summit-ului a fost acela de a evidenția obiectivele care au fost realizate în ultimii zece ani și care au vizat douăsprezece domenii critice, identificate de Platforma de la Beijing, șapte dintre acestea fiind considerate

condiție necesară pentru realizarea obiectivelor UE de creștere, ocupare a forței de muncă și coeziune socială. Încă din 1996, Comisia Europeană și-a asumat două abordări complementare în realizarea egalității de gen: gender mainstreaming și implementarea măsurilor specifice pentru eliminarea, prevenirea sau reducerea inegalităţilor de gen.

38 Ulterior, nevoia de a implementa pe deplin obiectivele stabilite la Beijing a fost exprimată în cadrul celei de-a 23-a dezbateri speciale a Adunării Generale „Femei 2000”. Delegațiile guvernelor, pe lângă progresele semnificative, au recunoscut persistența unor obstacole considerabile și apariția unor noi provocări.

${ }^{39}$ United States Department of State Reports, World Health Organisation Papers, Female genital Mutilation, February 1997. 
prioritare, și anume: dreptul la educaţie; dreptul la sănătate și la reproducerea umană asistată; dreptul la odihnă și timp liber; dreptul la proprietate și moștenire; dreptul la muncă; dreptul la reprezentare politică; protecția împotriva tuturor formelor de violență.

Datele raportate arată că multe dintre obiectivele stabilite în ambițioasa platformă de la Beijing nu au fost încă atinse. Cu toate acestea, este reiterată o voință puternică și durabilă a statelor membre în această directie.

În afară de conferințele amintite, la 20 septembrie 2000, șefii de stat din 191 de țări au semnat „Declarația ONU a Mileniului” (ODM), care includea opt obiective de dezvoltare ale mileniului (ODM), ce urmau a fi realizate până în 2015.

Aceste obiective stabilite sunt:

1) eradicarea sărăciei extreme și a foametei la nivel mondial;

2) dezvoltarea învățământului primar;

3) promovarea egalității de gen și a autonomiei femeilor;

4) reducea mortalității copiilor;

5) îmbunătățirea sănătății materne;

6) combaterea HIV/SIDA, a malariei și altor boli;

7) garantarea sustenabilităţii mediului;

8) dezvoltarea unui parteneriat global pentru dezvoltare.

Obiectivele prioritare de atins până în anul 2005 făceau referire la: promovarea egalităţii de gen şi autonomia femeilor, eliminarea inegalităţii de gen în învățământul primar și secundar pentru toate nivelurile de învăţământ, până în $2015^{40}$.

\subsection{Conferința ONU organizată la New York (2005): „Beijing + 10”}

În perioada 28 februarie - 11 martie, ONU organizează cea de-a cincea Conferință Internațională privind femeile (CSW). Delegații din peste o sută de țări au discutat statutul femeilor în lume, la treizeci de ani de la prima Conferință organizată în Mexico City și la zece ani de la Conferinţa istorică de la Beijing din 1995, în cadrul căreia a fost lansată „Platforma de acțiune”, care a schimbat radical perspectiva și abordarea politicilor de gen în întreaga lume, introducând principiile de: empowerment, mainstreaming, „împuternicire” și „integrare”, dar mai ales afirmând egalitatea de șanse între femei și bărbați și nediscriminarea femeilor, drept valoare universală, în toate sectoarele vieții publice și private.

Scopul summit-ului a fost acela de a verifica care dintre obiective au fost realizate în ultimii zece ani, mai exact în raport cu obiectivele strategice ale celor douăsprezece domenii critice identificate de Platforma de la

${ }^{40}$ ONU (2000), Dichiarazione del Millennio (Millennium Declaration), în
www.un.org/millennium/declaration/ares552e.htm, data accesării 3.12.2019. 
Beijing drept priorităţi absolute de intervenție: sărăcia, educația și formarea, sănătatea, violenţa, conflictele armate, economia, puterea și procesele decizionale, mecanismele instituţionale, drepturile omului, informația și mass-media, mediul, condiția femeilor.

Conferința s-a deschis cu o declarație de intenție din partea Comisiei privind statutul femeilor, în care a fost reconfirmată validitatea deplină a obiectivelor de la Beijing 1995, unde toate guvernele și organismele internaționale au fost invitate să-și intensifice eforturile de îmbunătățire a condițiilor de trai ale femeilor din lume, eliminând toate formele de restricționare, violența și discriminarea.

Conferința de la New York a fost precedată de mai multe conferinţe pregătitoare, desfãşurate în diferite zone ale lumii: cele pentru Europa au avut loc la sediul ONU de la Geneva, în ianuarie și februarie 2005. În timpul acestor evenimente, Guvernele naționale, care au aderat la Platforma de la Beijing, au fost invitate să se prezinte la Comitetul ONU pentru eliminarea discriminării împotriva femeilor și la Comisia pentru statutul femeilor, care a organizat și a gestionat activitatea Conferinței Internaţionale de la NewYork, prin rapoarte periodice, pentru o evaluare colegială a progresului înregistrat în politicile de implementare în fiecare țară.

\section{Concluzii}

La finalul acestei lucrări, doresc să subliniez rolul esențial jucat de ONU, atât prin conferințele mondiale, cât și prin sesiunile speciale organizate de Adunarea Generală cu privire la statutul și drepturile femeilor. Toate aceste Conferințe au reprezentat, cu siguranță, o experiență fundamentală pentru identificarea problemelor critice cu privire la drepturile femeilor, a egalității de gen, precum și la elaborarea unor răspunsuri eficiente capabile să creeze structuri și un angajament global în lupta împotriva discriminării pe criterii de gen. În acest sens, este suficient să amintim organismele înființate, care au avut un rol important în promovarea drepturilor femeii: „Convenția pentru eliminarea tuturor formelor de discriminare împotriva femeilor CEDAW", considerat primul instrument internațional obligatoriu din punct de vedere juridic, specializat pe conceptul de discriminare sau „Fondul de Dezvoltare a Naţiunilor Unite pentru Femei - UNIFEM”, un alt instrument prin care progresul și tendința de schimbare în bine a femeilor în rândul țărilor sărace s-au făcut vizibile. În cadrul Conferinței de la Nairobi - Kenia din 1985, a fost adoptat un document intitulat „Strategii viitoare de acțiune pentru promovarea femeilor, adoptate la Nairobi - NFLS" care prevedea: dezvoltarea instrumentelor legislative adecvate, egalitate în ceea ce privește participarea socială, egalitate în procesul politic și de luare a deciziilor deoarece până atunci multe state membre nu au avut intenţia să schimbe legislația pentru a progresa în acest domeniu. De asemenea, putem spune că s-au observat mari progrese în rândul statelor occidentale, dar și în Europa 
Centrală și de Est, prin contribuția adusă de Uniunea Europeană, prin politicile întreprinse în ultimii 30 de ani. Conferințele au dus la identificarea acelor domenii critice care impuneau angajamentul imediat al comunităților internaționale să intervină, cum ar fí: sărăcia, conflictele armate, violența în familie și marginalizarea. Din păcate, în secolul XXI, constatăm că, în multe state ale lumii din continentele Africa și Asia, unde, datorită tradițiilor sau practicilor religioase, progresul a fost aproape nesemnificativ, situația tinde să se agraveze, din cauza numeroaselor conflicte care au apărut, precum și a transformărilor profunde ale contextului macroeconomic. Astfel de atitudini trebuie eliminate prin educație și campanii de conștientizare în rândul tinerilor. Doar în acest fel putem spera la o societate mai bună și mai dreaptă.

\section{Bibliografie}

Cassese A., I diritti umani oggi, Bari, Laterza, 2009.

Cristaldi F., Nazioni unite e politiche di genere: Un processo in via di sviluppo, în Bollettino della Società geografica italiana, XI, 2006, p. 849.

Degani P., Diritti umani e violenza contro le donne: recenti sviluppi in materia di tutela internazionale, Maerne (Venezia), Eurooffset, 2000.

Delbrück J., Wolfrum R., German year Book of international law, vol. 36, Berlin, Duncker \& Humblot, 1993.

Hermann Conny, Verlag J.H.W Dietz Nachf, Das Recht auf Weiblichkeit: Hoffnung im Kampf gegen die Genitalverstümmelung, Taschenbuch, 2000.

Johansen R.E.B., Ziyada M.M., Shell-Duncan B. et al., Health sector involvement in the management of female genital mutilation/cutting in 30 countries, în „BMC Health Serv Research” 18, 240 (2018) doi:10.1186/s12913-0183033-x.

Loescher G., Refugee and international relations, Oxford, Clarendon Press, 1990.

Manfredi M., Mangano A., Alle origini del diritto femminile: cultura giuridica e ideologie, Bari, Edizioni Dedalo, 1983.

Manjoo R., Violenza contro le donne: cause e conseguenze, Roma, ONU, 2012.

Sperduti G., Studi in onore di Giuseppe Sperduti: fonti internazionali e rapporti fra ordinamenti; l'individuo nel diritto internazionale; altri contributi, Milano, Giuffré, 1984.

Spinelli A., Rapporto Ombra - Elaborato dalla piattaforma italiana. Lavori in Corsa: 30 anni CEDAW" in merito allo stato di attuazione da parte dell'Italia della Convenzione ONU per l'Eliminazione di Ogni Forma di Discriminazione nei Confronti della Donna (CEDAW), la Pubblicazione riferita al VI Rapporto presentato dal Governo italiano nel 2009, în www.retepariopportunita.it, data accesării: 14.06.2019. 


\section{Webografie}

Carta Națiunilor Unite, în http://legislatie.just.ro/Public/DetaliiDocument/19362, data accesării: 20.10.2019.

European Courts of Human Rights, în https://www.echr.coe.int/Pages/home.aspx?p=home, data accesării: 22.11.2019.

First World Conference on Women, Mexico 1975. Choike, Third World Institute, în https://www.unsystem.org/content/first-world-conference-women-1975-0, data accesării: 23.11.2019.

I diritti umani delle donne: dalla Dichiarazione Universale del 1948 alla Conferenza di Pecchino del 1995, în https://www.studiocataldi.it/doc/olivieri/cap2.asp, data accesării: 03.12.2019.

Le conferenze internazionali sulla donna, în http://unipdcentrodirittiumani.it/it/schede/Le-Conferenze-internazionali-sulladonna/382, data accesării: 12.10.2019.

Monitorul Oficial al României, în http://www.expert-monitor.ro/expertmonitor/Demo/index.jsp, data accesării: 12.06.2019.

ONU (2000), Dichiarazione del Millennio (Millennium Declaration), în www.un.org/millennium/declaration/ares552e.htm, data accesării 3.12.2019.

United Nations în https://www.un.org/en/, data accesării 10.11.2019.

United States Department of State, în https://www.usa.gov/federal-agencies/u-sdepartment-of-state, data accesării: 22.10.2019.

Universal Declaration of Human Rights, în https://www.ohchr.org/en/udhr/pages/Language.aspx?LangID=itn, data accesării: 10.11.2019.

World Health Organization, în https://www.who.int/, data accesării: 23.10.2019. 